ROSTYSLAV SOSSA

Lviv Polytechnic National University

National Academy of Sciences of Ukraine, Institute of History of Ukraine

Lviv, Ukraine

orcid.org/0000-0002-0335-6067

rostyslav.i.sossa@lpnu.ua

\title{
Contemporary status of topographic mapping in Ukraine
}

\begin{abstract}
The fundamentals and contemporary status of topographic mapping of Ukraine's territory has been studied. Prior to declaration of Ukraine's independence, its territory was covered with 1:10,000 to $1: 1,000,000$ scale topographic maps made by sub-divisions of the Chief Department of Geodesy and Cartography affiliated with the Council of Ministers of the USSR (GUGK USSR) and sub-divisions of the Military Topographic Service (MTS) of the USSR Armed Forces. Topographic mapping related cooperation between these institutions has been described. Topographic study of Ukraine's territory as at 1991 has been subject to close analysis, with due consideration of the coordinate systems used for topographic maps.

During the first years after Ukraine's independence declaration topographic maps in Ukraine were made according to the previously effective Soviet instructions in the 1942 coordinate systems and 1977 Baltic height system. Since mid 1990s, Ukraine enjoyed transition from analog technology of making topographic maps to digital one. The contemporary legal and statutory support of topographic mapping in Ukraine has been studied; the implementation since 1 January 2007 of the UCS-2000 national geodetic reference coordinate system and the height system measurement works have been analyzed. Focus has been made on obsolescence of information of contemporary topographic maps and on extensive deprivation of secrecy for topographic maps in 2000s.

Critical for the development of topographic mapping in Ukraine is now the Law of Ukraine "On National Geospatial Data Infrastructure" adopted in 2020. The Topographic Service of the Armed Forces (TS AF) of Ukraine carried out big scopes of works to update the topographic maps related to Russia's military operations against Ukraine.
\end{abstract}

Keywords: topographic maps, topographic mapping of Ukraine, National Geospatial Data Infrastructure, coordinate and heights systems

The availability of regularly updated geospatial information is important for safeguarding the defense capacity and for developing the productive powers of the country. Such information has traditionally been available in topographic maps, which major features are precision, reliability, visualization, and presentation of location in its current condition. In most countries, topographic mapping has a national status and is exercised by state services for geodesy and cartography, usually a civil service for geodesy and cartography and a topographic service of the armed forces. In cartography-developed countries, certain topographic map-making traditions and approaches are maintained, which manifest themselves in the information these maps contain and in the message this information brings, in selection of map scales, in use of symbols etc. Scientific, technical and technological development continuously inspires to improve the system of cartographic support for the needs of the state and the society. Broad implementation of geoinformation technology in map making and using requires new approaches in organizing the collection of spatial information and the message it brings. Since mid 1990s, creation of national infrastructures of geospatial data has gained a degree of priority development in spatial information procurements. 
Ukraine's system of topographic mapping, which has historically formed in the Soviet times, is for long pending reformation.

The issues of Ukraine's topographic mapping development, condition and problems are highlighted in numerous publications (Dyshlyk et al., 2006; Karpinskyi \& Liashchenko, 2006; Katrenko et al., 2006; Sossa \& Holubinka, 2017; Sossa, 2014). The fundamentals of and general requirements to making and updating the national topographic maps are outlined in the "Procedure for Nationwide Topographic and Thematic Mapping", as approved by Regulation No. 661 of the Cabinet of Ministers of Ukraine dd. 4 September 2013. Strategic direction in the development of topography, geodesy and cartography operations is outlined by the 2020 Law of Ukraine "On National Geospatial Data Infrastructure" enacted starting 1 January 2021. The research of major topographic mapping reformation principles in the context of development of the National Geospatial Data Infrastructure, development of architecture of the principal national topographic map in Ukraine, creation and development of a permanent system of topographic monitoring is made by Karpinsky, Lyaschenko, Lazorenko-Hevel in the Research Institute of Geodesy and Cartography and in Kyiv National University of Construction and Architecture (Karpinsky \& Lazorenko-Hevel, 2018, 2019; Karpinsky et al., 2011; Karpinsky \& Lyaschenko, 2010). Still, the issues of practical implementation of the idea to make a new system of topographic maps lack sufficient investigation.

The objective of the article is to study the contemporary status of topographic mapping in Ukraine.

After the extraordinary session of the Supreme Council of the Ukrainian Soviet Socialist Republic (USSR) adopted the Declaration of Independence of Ukraine on 24 August 1991, an issue of making its own service for geodesy and cartography arose. On 1 November 1991, Resolution No. 306 of the Cabinet of Ministers of Ukraine declared to initiate the Chief Department of Geodesy, Cartography and Cadastre at the Cabinet of Ministers of Ukraine (Ukrgeodezkartografia) to procure the Ukrainian economy with topography and geodesy materials and with mapping products and to make the basis for the State Cadastre. Ukrgeodezkartografia's structural divisions were 8 enterprises and companies of the Chief Department of Geodesy and Cartography of the USSR (GUGK USSR) then operating in Ukraine. After the declaration of Ukraine's independence on 1 December 1991, the Topographic Service of the Armed Forces (TS AF) of Ukraine was made.

In late 1991, Ukraine's territory was covered with $1: 10,000$ to $1: 1,000,000$ scale topographic maps made by sub-divisions of GUGK USSR and of the Military Topographic Service (MTS) of the USSR Armed Forces. Since late 1960s, close cooperation has been established in USSR between GUGK and MTS on the country mapping related issues. Very important for developing the civil service was its inclusion in the USSR military production sector, which, alongside considerable financial opportunities, contributed heavily to harmonized prospective and annual planning with MTS of doing the nationwide topography, geodesy and cartography works and to joint preparation of technical regulations being uniform for all departments and divisions. As a result of such cooperation, the state was procured with topographic maps of all scales and topographic plans of cities and towns subject to regular updates.

Topographic maps of USSR's territory (and Ukraine's territory, accordingly) were made in strict consistency from larger-scale maps to smaller-scale maps $(1: 10,000,1: 25,000,1: 50,000$, $1: 100,000$ etc.) with due consideration of cutting the territory into sheets of 1:50,000 scale topographic maps and smaller ones. In USSR, all topography, geodesy and cartography works were subject to extreme secrecy, and all topographic maps were "secret"-marked.

After World War II, topographic maps in USSR were made in the 1942 coordinate system (CK-42) and 1977 Baltic height system (earlier - 1946 Baltic height system). In 1963, subject to the "Cold War" between USSR and USA, an intentionally distorted provisional coordinate system of 1963 was created, in which large-scale maps were made. 1:10,000, 1:25,000 and $1: 100,000$ scale topographic maps in the CK-63 coordinate system were made by GUGK's companies. 1:50,000, 1:100,000, 1:200,000, $1: 500,000$ and $1: 1,000,000$ scale topographic maps were made by MTS's sub-divisions solely in the CK-42 coordinate system. Given huge scopes of MTS's works in topographic mapping of foreign territories, civil topographical surveyors and mapmakers were involved continuously in 
those works. For Ukraine's territory, about $60 \%$ (in some years up to $80 \%$ ) sheets of a 1:50,000 scale topographic map was updated, compiled and prepared for issue by Company No. 13 (since 1989 known as Pivdenno-Zakhidne; since 1991 known as the Ukrainian Aerogeodesy Enterprise). Since then, to cover Ukraine's territory, $1: 10,000,1: 25,000$ and $1: 100,000$ scale topographic maps in the CK-63 coordinate system appeared. In 1987, the 1963 provisional coordinate system was cancelled, and maps of the scales above were again made in the CK-42 coordinate system.

Soviet topographic maps, for their information and accuracy of geographic presentation, were attributed to world's best (Lee \& Shumakov, 2003).

We have researched the overall condition of comprehensive topographic study of Ukraine's territory (Sossa, 2014), which as at 1 January 1992 could be described as seen below.

Almost whole Ukraine's territory was in total covered by $1: 10,000$ scale topographic maps in the CK-63 and CK-42 coordinate systems. Unsurveyed and, as such, uncovered by maps of the above scale were left some areas in Carpathians and on the borderline in Lviv Oblast and Chernivtsi Oblast, which was predetermined by technical complexity of aerial survey works in the mountain locations under conditions of heavy clouds and by difficulties in making agreements about aerial aircraft turns above the neighboring countries.

By 1987, a 1:10,000 scale topographic map in the CK-63 coordinate system covered $82.3 \%$ Ukraine's territory; 24,162 sheets out of 29,358 were issued. In general, maps reproduced locations in their updated condition. The issued maps that covered $33.0 \%$ Ukraine's territory reproduced the locations in their condition of 5 to 10 years ago; $31.8 \%$ Ukraine's territory of 10 to 15 years ago.

Even before the CK-63 coordinate system was officially cancelled in March 1987, the issue of $1: 10,000$ scale topographic maps in the CK-42 coordinate system put on hold after 1964 was resumed. Although almost 2,500 map sheets were annually prepared for issue and further issued in 1990-1991, nonetheless as at $1 \mathrm{Ja}-$ nuary 1992 a $1: 10,000$ scale topographic map in CK-42 covered only 53.0\% Ukraine's territory $(15,586$ sheets out of 29,395 were issued). $28.5 \%$ Ukraine's territory was procured with maps reproducing the locations in their condition of more than 30 years ago, and only $16.4 \%$ Ukraine's territory of up to 5 years ago.

By the end of 1991, 1:25,000 scale topographic maps in the CK-63 coordinate system were issued for $94.6 \%$ Ukraine's territory. The attention paid to updating those maps was not the same as the attention paid to a 1:10,000 scale map in the CK- 63 coordinate system. The maps with more than 30 years ago update covered $37.7 \%$ Ukraine's territory. The qualitative evaluation of condition of coverage $(99.7 \%)$ by a 1:25,000 scale topographic map in the CK-42 coordinate system shows even worse situation with the age of updates on the maps issued as at 1 January 1992. 68.3\% existing maps had more than 30 years ago update.

By the end of 1987, almost whole Ukraine's territory $(99.6 \%)$ was covered by a $1: 100,000$ scale topographic map in the CK-63 coordinate system for economic purposes. Most map sheets were re-issued with updated information in 1985-1987. 530 sheets out of 532 were issued, which covered Ukraine's territory. The information of $51.5 \%$ issued maps was 10 to 15 years old; of $36.5 \%$ issued maps 15 to 20 years old.

The principal military map was a 1:50,000 scale topographic map, which covered Ukraine's territory in full. The map had a good level of location update. As at 1 January 1992, 39.5\% issued 1:50,000 scale maps had up to 5 years ago update, another $39.5 \%$ maps had 5 to 10 years ago update. The coverage of Ukraine's territory by a $1: 100,000$ scale topographic map in CK-42 (528 sheets) was also good. Up to 5 years ago update was inherent in $23.1 \%$ issued maps as at 1 January 1992; 5 to 10 years ago update in $48.5 \%$; more than 15 years ago update in $10.2 \%$.

Older was the information in a 1:200,000 scale topographic map (156 sheets). Only $9.0 \%$ issued maps of this scale had up to 5 years ago update; $51.9 \%$ had 5 to 10 years ago update. Ukraine's territory was also covered by $1: 500,000$ scale topographic maps (26 sheets) and 1:1,000,000 scale topographic maps ( 9 sheets), but the issue of their updated versions gradually decreased.

Establishing Ukraine's own state service for geodesy and cartography initiated a contemporary stage of its mapping. However, during the first years after Ukraine's independence declaration topographic maps in Ukraine were 


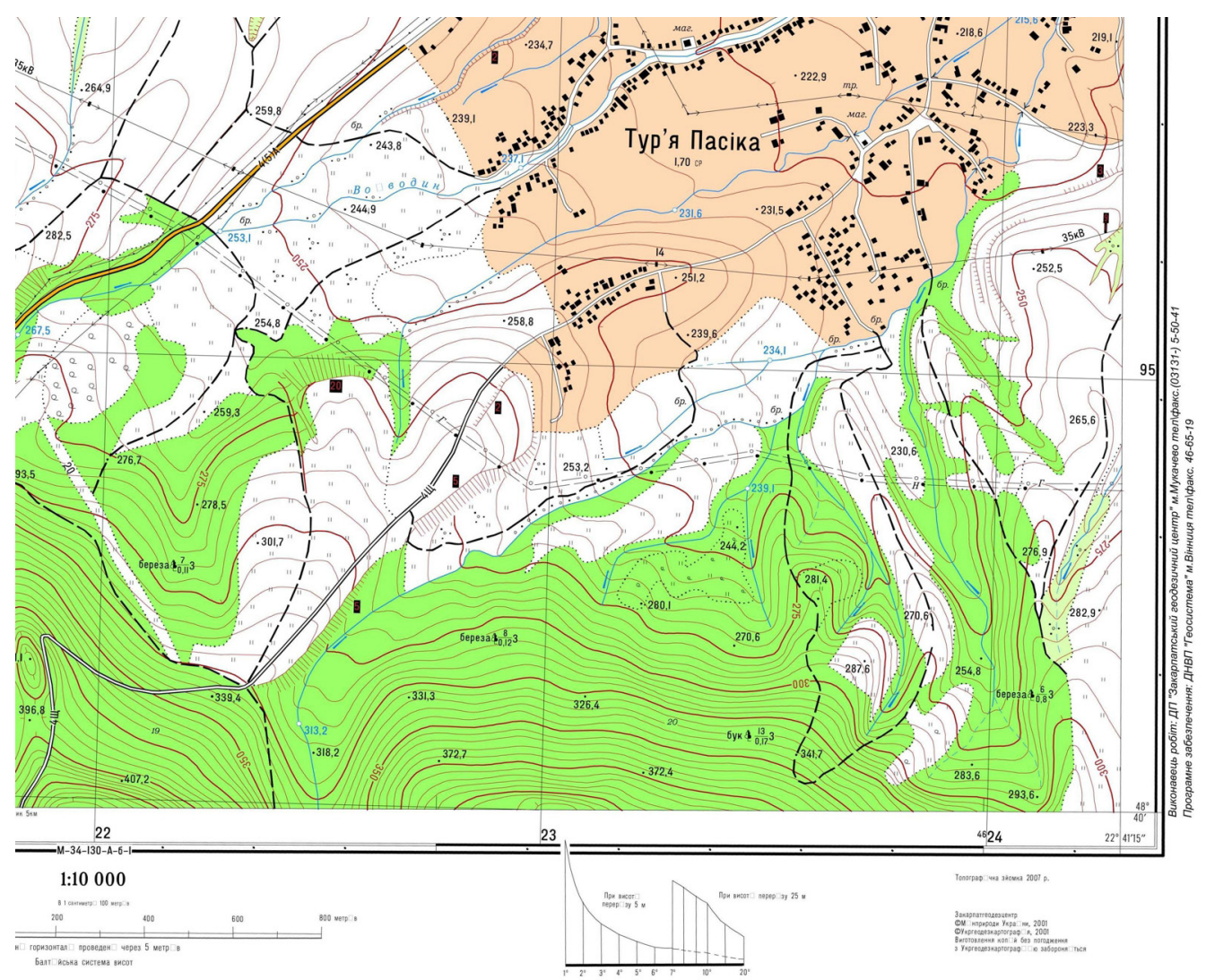

Fig. 1. A part of the nationwide 1:10,000 scale topographic map

made according to the previously effective Soviet instructions in the 1942 coordinate systems and 1977 Baltic height system (Osnovnye..., 1984). Starting 2000, the general requirements to the geodetic base, precision and information of the nationwide topographic maps of all scales in Ukraine are outlined in the new technical regulations, which, only slightly amended, overall duplicate those previously effective Soviet instructions (Osnovni..., 2000). The type of topographic maps historically developed in USSR and the then used coordinate systems and height systems, as well as symbols remained unchanged (figs. 1-3).

In 1993, it was decided to issue topographic maps in the national, Ukrainian, language.

During 1990s, Soviet security restrictions were still in place and effective in the already independent Ukraine in the areas of topography, geodesy, gravimetric and cartography works, aerial and satellite surveys. The level of secrecy, procedures for production, storage, distribution and use by companies and organizations of topographic maps and plans, coordinates of geodetic points and geographic locations were still regulated by the Soviet instructions that governed the designation and provision of secrecy of topography, geodesy, cartography gravimetric, aerial survey materials.

Since late 1990s, Ukraine enjoys gradual transition from analog technology of making topographic maps to digital one. It is reasonable to mention here the successful development of Ukraine's own photogrammetry instrument making industry, which contributed to the transition of Ukrainian topography and geodesy companies to digital technology in making primary topographic maps. "Geosystema" / "Geosystem" 


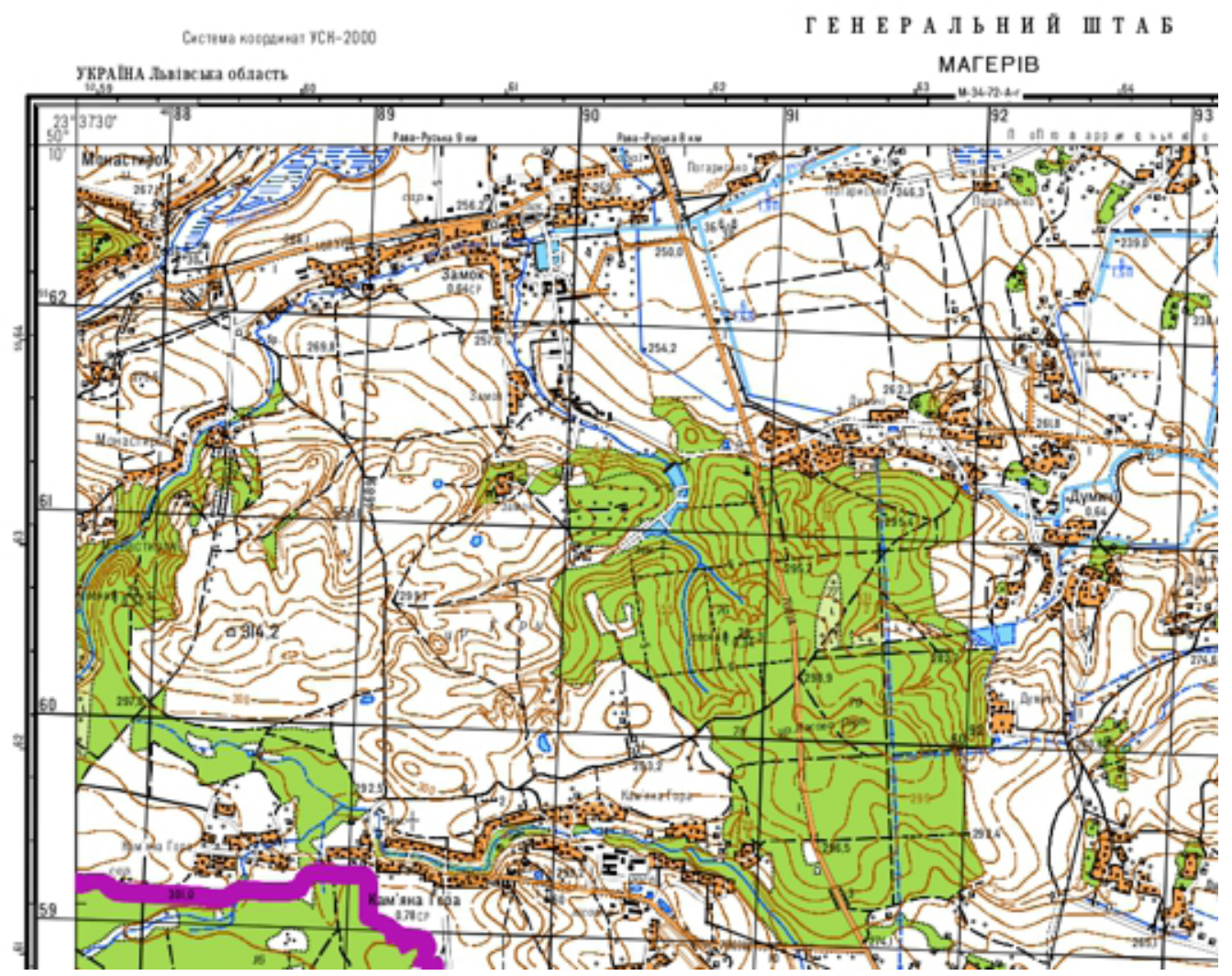

Fig. 2. A part of the nationwide 1:50,000 scale topographic map

State Research and Production Company (Vinnytsia) launched the issue of high-precision photogrammetric scanners, digital photogrammetric stations and digital aerial cameras, which turned to be of high demand in many world's developed countries. Digitals software developed by "Geosystema" is widely used in topographic and cadastre works.

Now, topographic maps and plans in Ukraine are prepared according to the contemporary geoinformation technology. They are made in the system of topographic information classification and encryption according to the rules of digital description of topographic objects and as per accepted storage format (Klasyfikator..., 2000). Digital topographic maps are made and updated by the state-owned companies of cartography and geodesy industry and the Military Topographic Service sub-divisions.
The mathematical framework of the nationwide topographic mapping is the State Geodetic Control of Ukraine, which had previously been established as part of the USSR geodetic control. It includes arc triangulation, supplementary scheme of triangulation and traverse network of $1^{\text {st }}$ and $2^{\text {nd }}$ order, $3^{\text {rd }}$ and $4^{\text {th }}$ order control extensions, 1-1V order leveling networks. In early 2000 s, horizontal geodetic control consisted of 19,538 points (519 points - primary, 5,386 points - secondary, 13,633 points - tertiary and quaternary), and also had 90 geodetic azimuths based on astronomical observations, 49 bases and basis sides. A vertical geodetic control consists of 1-, IV-order leveling networks. The I- and 11-order leveling lines are the main elevation datum of Ukraine. They make 18 and 72 polygons, respectively. The total of I-order lines - 29 lines 11,975 km long, II-order lines 


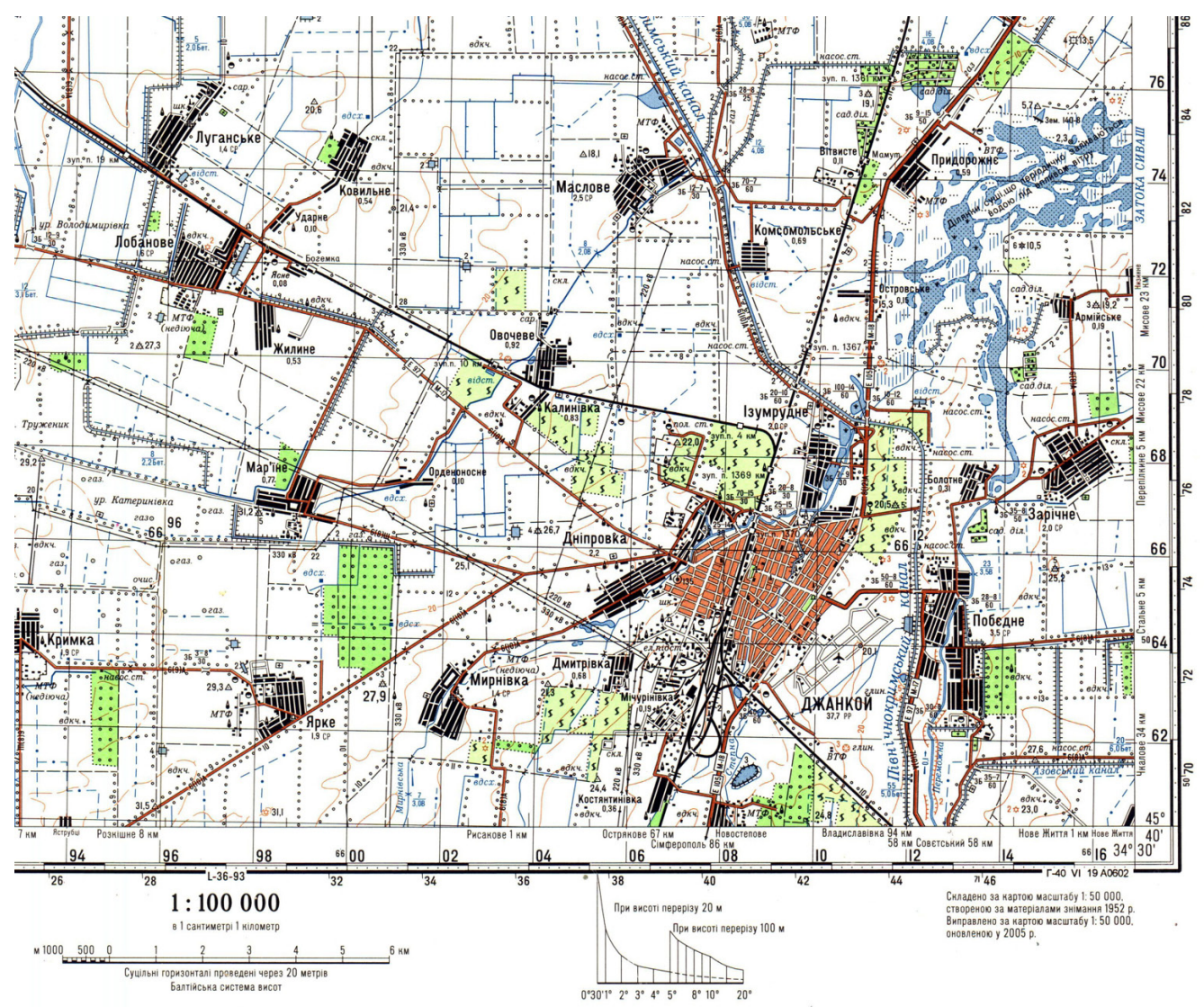

Fig. 3. A part of the nationwide 1:100,000 scale topographic map

- 62 lines 11,180 km long. The national gravimetric network consists of 55 primary points, of which 17 points are fundamental. Materials of the measurements made as far back as the Soviet times are still not organized and catalogs of points of gravimetric network of Ukraine still not compiled (Dyshlyk et al., 2006; Zaiets \& Kucher, 2006).

In late $X X$ century, due to the satellite and computer technology development and broad implementation, the then effective coordinate system (the 1942 coordinate system and 1977 Baltic height system) could not ensure anymore the level of precision of measuring the coordinates of the National Geodetic Control points so much required to meet the contemporary scientific and practical needs. Since 2002, the Research Institute of Geodesy and Cartography (Kyiv), with the involvement of scientists from
Lviv Polytechnic National University, has started the geodetic control modernization works. Research works have been initiated to model the parameters of a reference Ukrainian coordinate system - UCS-2000. The developed coordinate system is accurately agreed with the International Terrestrial Reference System JTRS/ITRF2000 at epoch 2005. The reference surface in the UCS-2000 coordinate system is a reference Krasovsky ellipsoid with the following parameters: semi-major axis - 6,378,245 m; flattening $-1: 298.3$. The new coordinate system was developed so that the size of trapezes of sheets, which constituted a 1:10,000 scale topographic map (CK-42), remained unchanged.

Following the Ukrainian Government's resolution, starting 1 January 2007 all topography, geodesy and cartography works in Ukraine should be done in the national geodetic refe- 
rence coordinate system UCS-2000. However, some ministries and departments, e.g. land department, still kept working in the previously effective coordinate systems for quite a while.

Now, regarding the elevation height system. It is known that during the EUREF symposium in Helsinki (1995), a proposal was made to bring together the existing EUREF network, regional leveling networks of Europe (UPLN and UELN) and a network of tide gauges into a single integrated network called UELN-95. Later, this network was joined by leveling networks of a number of Eastern European countries and of Switzerland. Accordingly, the name of the European leveling network was specified.

In 2009, Ukrgeodezkartografia agreed with the Federal Agency for Cartography and Geodesy (BKG) about processing Ukraine's results of I-order leveling together with the European Leveling network and about including the Leveling Network of Ukraine in the United European Leveling Network (UELN), which would contribute to popularization of the UELN/EVRS2000 European Vertical Reference System across Ukraine. The Federal Agency for Cartography and Geodesy has been designated as responsible for popularization of the UELN/EVRS2000 height system (United European Leveling Network/European Vertical Reference System of 2000) across Europe.

In 2009-2012, works took place to transfer I-order leveling materials from their hard copy to digital format. In 2018, as agreed with the State Service of Ukraine for Geodesy, Cartography and Cadastre (StateGeoCadastre), digital I-order leveling materials were passed to the Federal Agency for Cartography and Geodesy for joint leveling with the European Leveling Network.

In 2019, BKG provided the United European Leveling Network's leveling results with due consideration of Ukraine's leveling lines. The quality assessment to a tolerance of measurement of a difference of geopotential number per $1 \mathrm{~km}$ of leveling line in Ukraine is $1.71 \mathrm{kgal} \cdot \mathrm{mm}$.

Now, the Cabinet of Ministers of Ukraine is underway with preparation of a regulation about joining the UELN/EVRS2000 height system (United European Leveling Network/European Vertical Reference System of 2000) and about using it in Ukraine.

No works on gravimetric network development in Ukraine are still in progress.
Since mid 1990s, as the government has rapidly reduced its financing to the state service for geodesy and cartography for the purposes of topography and geodesy works, the scopes of aerial survey, topographic map update and printout have decreased significantly. Especially abrupt was the decrease in work scopes after 1997. The then effective government technical regulations, depending on the location being situated in this or that physiographic region, on man-made load and on the number of changes occurred in a location, envisaged some definite update frequency for topographic maps of all scales: for industrially developed densely populated areas $-5-7$ years; for agricultural middle-populated areas $-8-10$ years; for mountain, forest and steppe low-populated areas - 10-15 years. However, the update frequency timing recommended for topographic maps by the instructions is not observed. That is why the information of most issued $1: 10,000$ to $1: 200,000$ scale topographic maps is obsolete and does not reproduce the actual location status.

After 1987, Ukraine ceased to make topographic maps in the CK-63 coordinate system. Still, until very recently, the $1: 10,000$ and $1: 25,000$ scale topographic maps in the CK-63 coordinate system, which had limiting "For internal use" tags (topographic maps of the same scales in CK-42 were secret), were utilized for land-use works. Most of those maps reproduce the information, which is more than 30 years old.

In the first half of and in mid 1990s, the key priority in making $1: 10,000$ and $1: 25,000$ scale topographic maps was to use those maps to cover the territories not covered by them before, because during 1963-1987 those maps were only made in the CK-63 coordinate system. As at 1 January 2013, 22,433 (out of 29,395) sheets of a 1:10,000 scale topographic map in CK-42 covering 62.3\% Ukraine's territory were issued. Still, more than a half of the issued $1: 10,000$ scale maps is obsolete, with the locations reproduced on $65.5 \%$ maps being more than 20 years old.

Almost whole Ukraine's territory is covered by a $1: 25,000$ scale topographic map in CK-42 $(7,544$ sheets out of 7,554$)$. The existing maps also reproduce the information, which is mostly obsolete. As at 1 January 2013, less than 20 years old was only $16.1 \%$ issued $1: 25,000$ scale maps. 
It should be mentioned that the issue of large-scale topographic maps stopped after 1999. Therefore, the situation with map information obsolescence described here is even worse today. Such poor coverage of Ukraine's territory by topographic maps has become a logical consequence of frequent Ukrgeodezkartografia's reorganizations and re-subordinations, including its liquidations.

As at 1 January 2013, better was the situation with updates of the principal military $1: 50,000$ scale topographic map: up to 5 years $-3.4 \%$ issued maps; 5 to 10 years $-29.1 \%$; 10 to 15 years $-62.8 \%$; over 15 years $-4.7 \%$.

The worst was the quality of location reproduction in a 1:100,000 scale topographic map where $90.1 \%$ sheets had the more-than-20-years-old information. Still, we should note that 116 sheets of a $1: 100,000$ scale map that reproduced the locations as at 1990s and 2000s were prepared for issue but never printed out.

As a positive factor, we should note that a considerable step forward was made in 2000s to deprive topographic maps (scales 1:100,000 $-1: 1,000,000)$ of their secrecy. In a new wording of the "Summary of Information That Constitutes the State Secret" (hereinafter, the "Summary") published in the Official Bulletin of Ukraine dd. 13 April 2001, 185 out of 271 articles from the previous Summary were revised (including the precision limit to measure the coordinates of geodetic, astronomical, gravimetric points and restricted access facilities was decreased from 35 to $20 \mathrm{~m}$ ). Following the Law of Ukraine "On the State Secret", based on the Summary above, an Extensive List of Information That Constitutes the State Secret was approved on 19 November 2001 in the system of the Ministry of Ecology and Natural Resources of Ukraine, which among other included Ukrgeodezkartografia back then. According to this Extensive List, a "secret" mark was taken off the 1:100,000 scale topographic maps; the 1:50,000 scale topographic maps and plans and larger ones in the CK-42 and CK-63 coordinate systems still remained secret.

According to the Summary of 12 August 2005, secret are the 1:50,000 scale topographic maps and plans and larger ones in the CK-42 and USK-2000 coordinate systems. Following the requirements of the Summary (as amended on 24 January 2006 and 25 April 2006), limiting
"For internal use" tags were assigned to the following topographic maps and plans: scales $1: 2000,1: 5000$ and $1: 10,000$ in the local coordinate system; scales 1:5000, 1:10,000 and $1: 25,000$ in the provisional coordinate system; scales $1: 10,000$ and $1: 25,000$ in the CK-63 coordinate system.

The next step in depriving the mapping information of secrecy was the changes introduced to the Summary on 25 November 2009, which removed the "topography, geodesy and cartography" paragraphs under Nos. 1.11.1 - 1.11.8 from the Summary. In the record of the meeting of an expert commission affiliated with the state expert in the area of secrecy in topography, geodesy and cartography operations of $22 \mathrm{Ja}$ nuary 2010, the following was attributed to confidential information with limiting "For internal use" tags:

- 1:10,000-1:50,000 scale topographic, digital maps, mosaics and mosaic maps and $1: 10,000-1: 25,000$ scale city layouts (whatever the information form and medium) for Ukraine's territory made in the national coordinate system UCS-2000 or in the CK-42 coordinate system, which contain exhaustive information for detailed study and evaluation of location, its navigation, target indication, making measurements and diverse economic and defense operations;

- information about precise values of navigation elements of the UCS-2000 and CK-42 coordinate systems and the connections these systems have with other coordinate systems;

- information about the coordinates of geodetic points for Ukraine's territory measured with precision of up to 10 meters in any coordinate system other than provisional and local.

The next step, on 17 July 2013, was removing the "For internal use" tags from topography, geodesy and cartography materials and data not belonging to defense issues.

Given Ukraine's Europe-oriented aspirations and as part of the "Partnership for Peace" cooperation program between Ukraine and the North Atlantic Treaty Organization, the topographic service of the Armed Forces of Ukraine studied the experience of NATO's cartographic support. Map-making sub-divisions of TS AF of Ukraine issued separate sheets of topographic maps according to NATO's standards maps of firing ranges in $1: 25,000$ and $1: 50,000$ scales, 1:100,000 scale maps. For the whole 


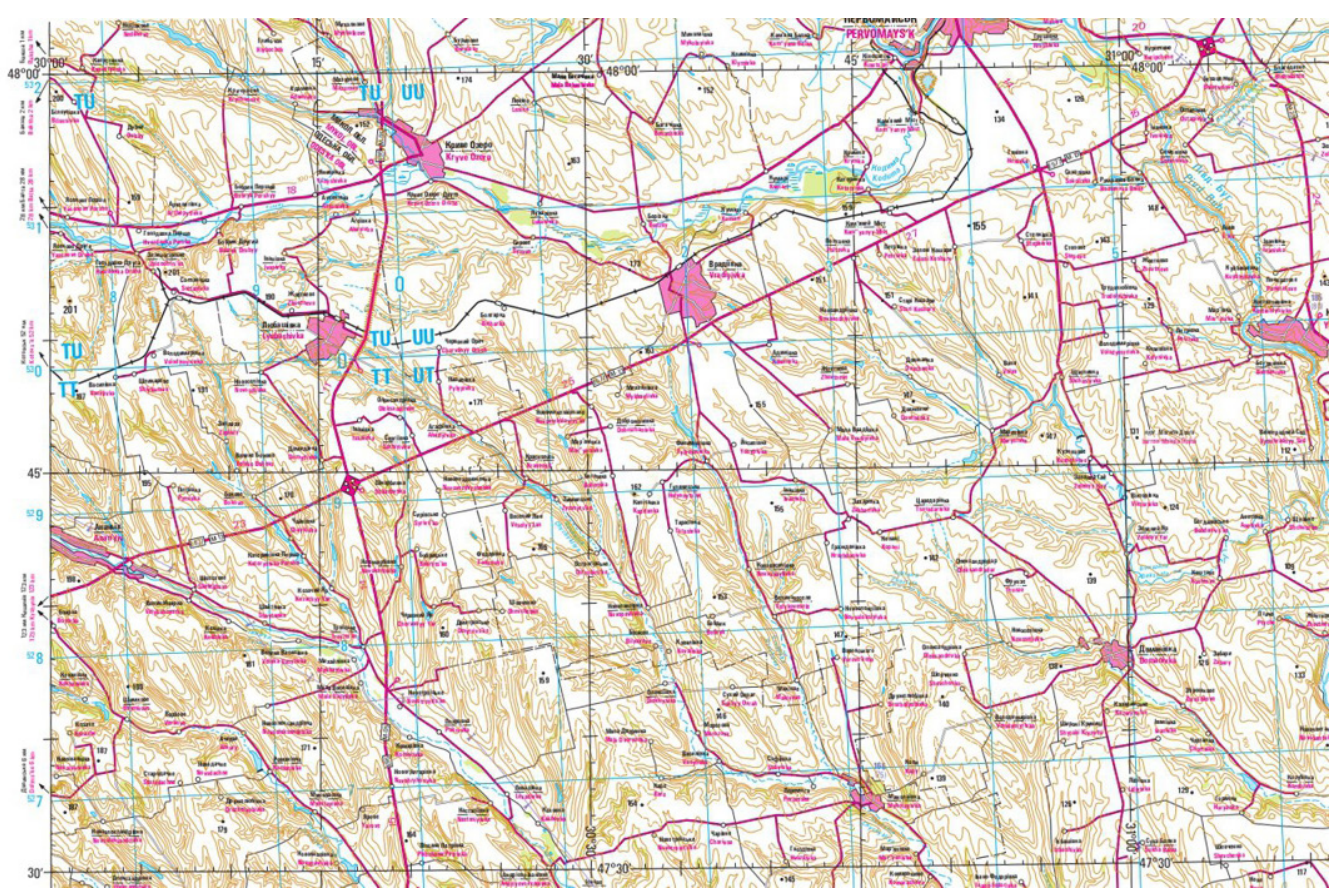

Fig. 4. A part of the 1:250,000 scale topographic map (JOB)

Ukraine's territory a 1:250 000 scale joint operations graphic (JOG) was made, of which only 10 sheets were issued (fig. 4). The maps were made in Ukrainian and English.

Subsequent development of the society primarily sets new tasks to topographic mapping. Use of automation, digital modeling, geoinformation system achievements has resulted in the need for national infrastructures of geospatial data. The needs of today's users of topographic information in Ukraine require considerable improvement of the content and update of topographic maps, opportunities for their prompt use. As far back as 2005, the Research Institute of Geodesy and Cartography came up with the strategy of making a national infrastructure of geospatial data in Ukraine. Principles were developed and approaches substantiated with regard to its creation; a set of primary statutory and technical regulations was outlined, to administer the creation and use of geospatial data by the government, self-government, entities and individuals. The composition and structure were substantiated for the information, technology and other components of the
National Geospatial Data Infrastructure, and feasibility calculations were made (Karpinskyi \& Liashchenko, 2006). However, the Law of Ukraine "On National Geospatial Data Infrastructure" was only adopted on 13 April 2020. This Law outlines the legal and organizational fundamentals for creation, operation and development of the National Geospatial Data Infrastructure aimed to help the government and self-government take effective management decisions, for satisfaction of needs of the society in all types of geographic information, for integration in the global and European Geospatial Data Infrastructures.

Today, the fundamentals of and general requirements to making and updating the national topographic maps are outlined in the "Procedure for Nationwide Topographic and Thematic Mapping", as approved by Resolution No. 661 of the Cabinet of Ministers of Ukraine dd. 4 September 2013. According to this Procedure, the nationwide topographic mapping in Ukraine should be now exercised in scales 1:10,000, $1: 25,000,1: 50,000,1: 100,000,1: 250000$, $1: 500,000$ and $1: 1,000,000$. Topographic maps 
of these scales are national. The principal national topographic maps are 1:10,000, 1:50,000, $1: 100,000$ and 1:250 000 scale topographic maps. The national base topographic map is a 1:10,000 scale topographic map. Based on national topographic maps, thematic and special maps are made.

In terms of their information, topographic maps should be split into maps with:

- harmonized content, which contain the open-to-the-public information about location objects and their descriptions and are intended for a wider audience;

- extended content, which are based on maps with harmonized content and supplemented with information about location objects and their descriptions and intended for whom it may concern;
- simplified content, which are based on maps with harmonized content, from which the information is removed according to the regulations that set requirements to reproducing location objects and their descriptions in maps. Such maps are a topographic basis to make thematic and cadastre maps and geoinformation systems.

Russia's occupation of Crimea and especially military operations in Donbas have evidenced serious drawbacks in topographic information procurements to Ukraine's security and defense sector, because the Armed Forces is the key user of topographic maps. Furthermore, the informational obsolescence of maps and their until-recently secret status have resulted in a low demand for such topographic maps. The geoinformation technology development has trig-

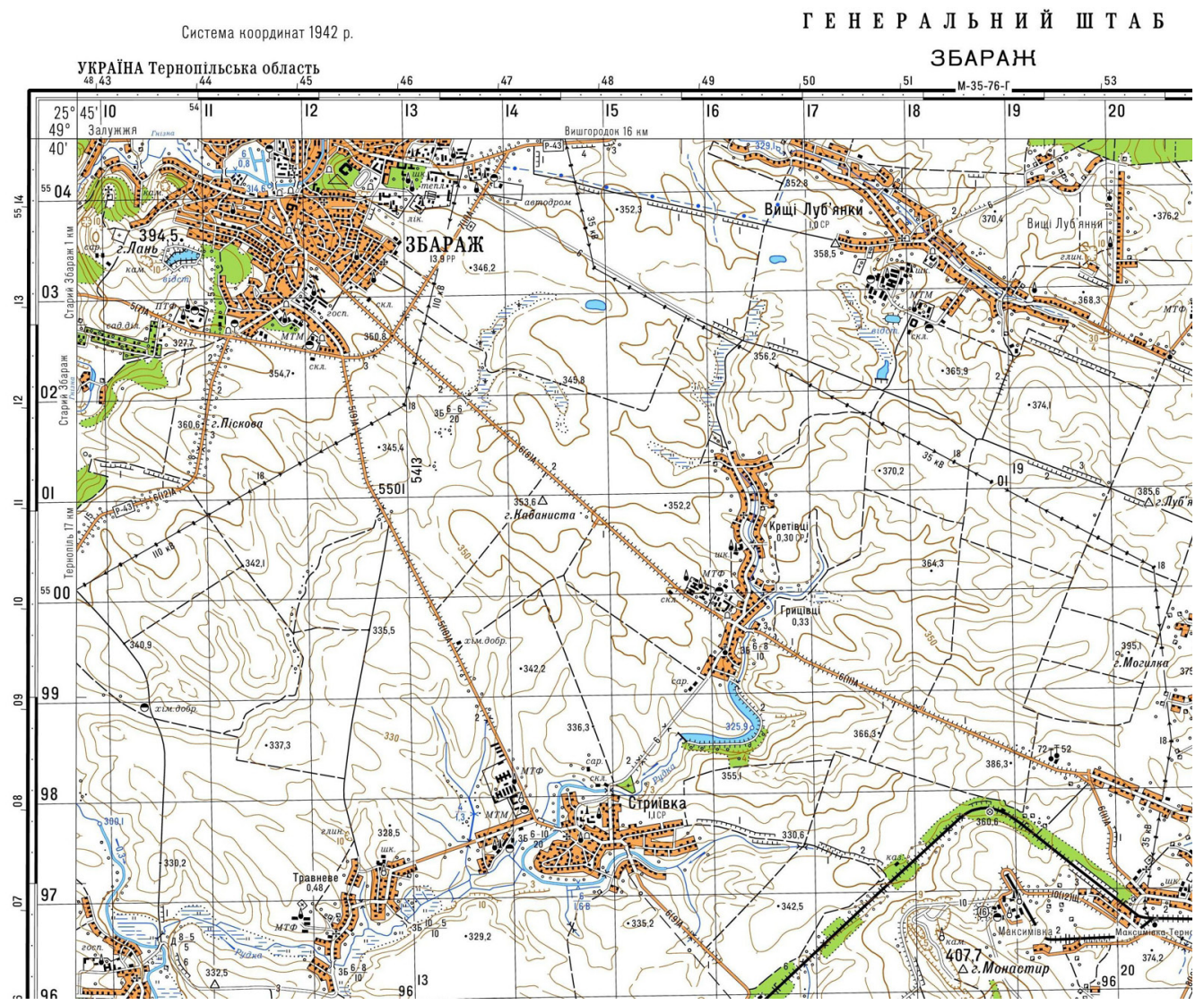

Fig. 5. A part of the traditional 1:50,000 scale topographic map (made according to the instructions for topographic maps) 
ГЕ Н Е РАЛЬНИЙ ІІІТА Б

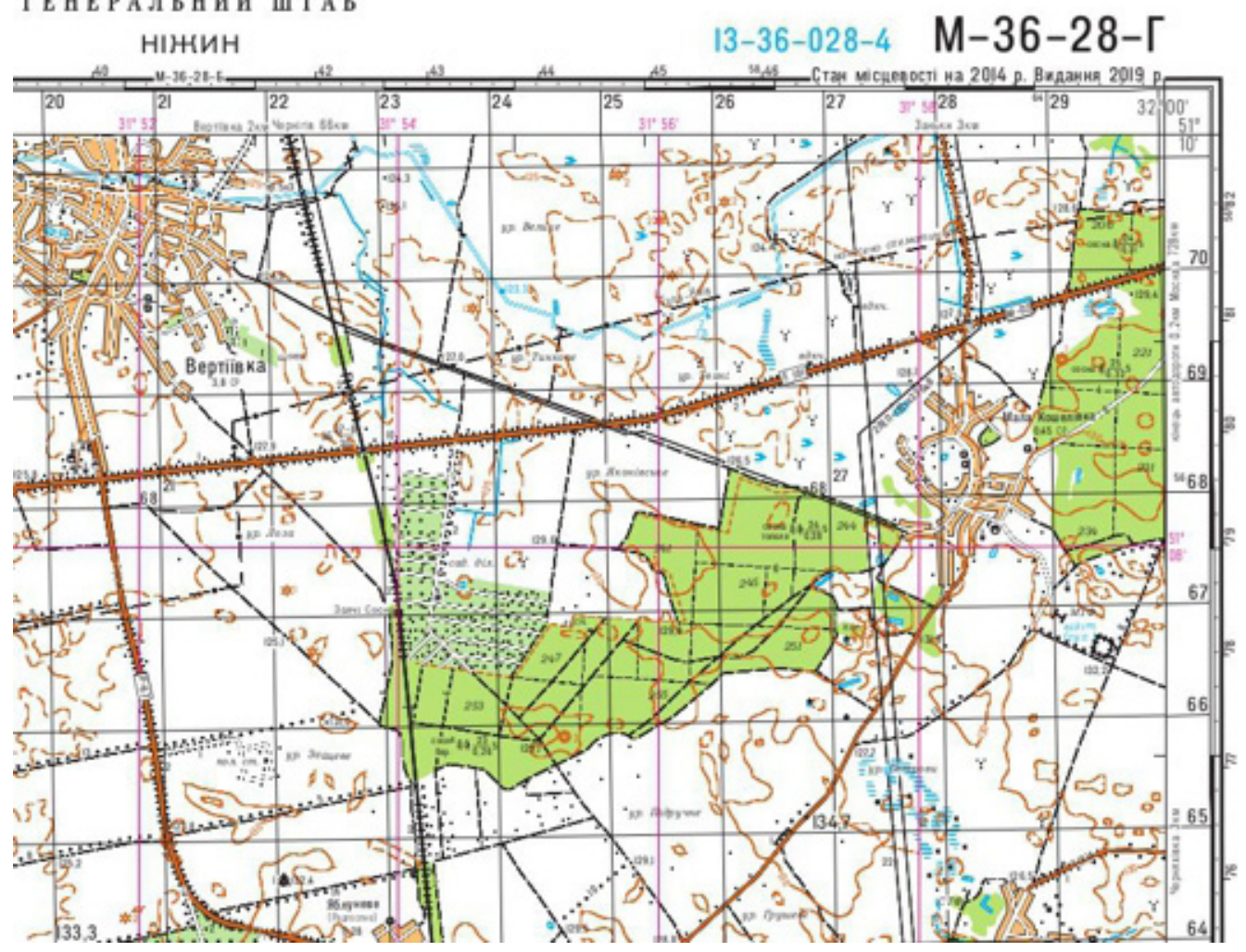

Fig. 6. A part of the special 1:50,000 scale map

(made in ArcGIS with a slight deviation from the instructions for topographic maps)

gered the need for geospatial information in a digital form and encouraged the discourse about whether hard-copy topographic maps are overall on demand. However, war actions in Donbas have proved hard-copy topographic maps are still needed.

It should be noted that after Russia began its military operations against Ukraine in 2014, TS AF of Ukraine carried out big scopes of works to update the $1: 50,000$ scale topographic maps. Mostly for the eastern regions of Ukraine more than 600 sheets of this map were re-issued, of which some sheets were updated and issued twice. 1:50,000 scale topographic maps are now open to the public. Depending on how those maps are made, there are two types of them. A traditional topographic map is made according to the instructions and using the symbols accepted for topographic maps (fig. 5). The need to accelerate the timing of map preparation for issue has resulted in the initiation of the so-called special map, which is made in ArcGIS with a slight deviation from the accepted instructions and symbols and with some simplifications of mapping reproductions (fig. 6). For example, separate buildings are not reproduced in city blocks, a WGS grid is made additionally etc. Other slight deviations from a traditional topographic map are related to the preparation of maps for their issue in ArcGIS.

Now, the implementation of an agreement between the State Service of Ukraine for Geodesy, Cartography and Cadastre, Ukrainian State Aerogeodesy Enterprise and the Norwegian Mapping Authority is coming to an end 
with regard to making a base of topographic data of the national 1:50,000 scale topographic map, making (updating) digital topographic maps on 122 sheets for Ukraine's territory. The agreement has been concluded as part of the "Maps to Promote Good Land Use in Ukraine" project, which is funded by the Ministry of Foreign Affairs of Norway.

Under this agreement, the objectives of making (updating) the digital topographic maps are as follows:

1) to make the Principal National Topographic Map as an aggregate of interrelated structured geospatial data in the base of topographic data and to make it available on the Geoportal of the Principal National Topographic Map to safeguard the updated status of the uniform digital topographic basis by way of initiating the topographic monitoring of location and to

\section{Literature}

Dyshlyk, O., Karpinskyi, Yu., Kucher, O., Lepetiuk, B., Lypskyi, V., Liashchenko, A., Markov, S., Sossa, R., Triukhan, M., \& Yashchuk, V. (2006). Stan ta osnovni napriamy rozvytku topohrafo-heodezychnoi i kartohrafichnoi diialnosti v Ukraini. Kyiv: NDIHK.

Karpinskyi, Yu., \& Lazorenko-Hevel, N. (2019). Arkhitektura osnovnoi derzhavnoi topohrafichnoi karty. In Kartohrafichne modeliuvannia ta heohrafichni informatsiini systemy: Zbirnyk materialiv vseukrainskoi naukovo-praktychnoi konferentsii (pp. 11-14). Lviv: Vydavnyctvo L'vivśkoji Politechniky.

Karpinskyi, Yu., \& Lazorenko-Hevel, N. (2018). Metody zbyrannia heoprostorovykh danykh dlia topohrafichnoho kartohrafuvannia. Suchasni dosiahnennia heodezychnoi nauky i vyrobnytstva, I (35), 204-211.

Karpinskyi, Yu. O., Liashchenko, A. A., \& Kvartych, T.M. (2011). Kontseptualni zasady stvorennia systemy derzhavnoho topohrafichnoho monitorynhu mistsevosti. Visnyk heodezii ta kartohrafii, 3, 27-31.

Karpinskyi, Yu. O., \& Liashchenko, A. A. (2006). Stratehiia formuvannia natsionalnoi infrastruktury heoprostorovykh danykh v Ukraini. Kyiv: NDHIK.

Karpinskyi, Yu. O., \& Liashchenko, A. A. (2010). Topohrafichne kartohrafuvannia $v$ Natsionalnii infrastrukturi heoprostorovykh danykh. In Natsionalne kartohrafuvannia: stan, problemy ta perspektyvy rozvytku (Vol. 4, pp. 52-60). Kyiv: DNVP «Kartohrafiia».

Katrenko, I. M., Lepetiuk, B. D., Triukhan, M. O., \& Shevchuk P. M. (2006). Topohrafichne kartohrafuvannia. In Derzhavna kartohrafo-heodezychna sluzhba Ukrainy (1991-2006) (pp. 97-114). Kyiv: NDIHK. develop the National Geospatial Data Infrastructure across Ukraine;

2) to prepare digital topographic maps for issue and to enter mapping information into the Mapping Information Database within the ArcGIS geoinformation system environment at the Topographic Service of the Armed Forces of Ukraine.

It is of relevance now in Ukraine to carry out aerial survey works aimed to update the base 1:10,000 scale topographic map.

Today's needs of Ukraine and its society in geospatial information prioritize big scopes of works in large-scale topographic mapping. The basic topographic information today is demanded as a fundamental collection of spatial data for the National Geospatial Data Infrastructure.

Klasyfikator informatsii, yaka vidobrazhaietsia na topohrafichnykh kartakh masshtabiv 1:10,000, 1:25,000, 1:50,000, 1:100,000, 1:200,000, 1:500,000, 1:1,000,000 (2000). In Topohrafo-heodezychna ta kartohrafichna diialnist: Zakonodavchi ta normatyvni akty (Vol. 2, pp. 189-221). Vinnytsia: Anteks.

Lee, K. D., \& Shumakov, A. (2003). Russian data illuminate world mapping. Imaging notes. Retrieved from http://gis-lab.info/docs/russian-topo.pdf

Osnovni polozhennia stvorennia ta onovlennia topohrafichnykh kart masshtabiv 1:10,000, 1:25,000, $1: 50,000,1: 100,000,1: 200,000,1: 500,000$, 1:1,000,000 (2000). In Topohrafo-heodezychna ta kartohrafichna diialnist: Zakonodavchi ta normatyvni akty (Vol. 2, pp. 171-188). Vinnytsia: Anteks.

Osnovnye polozhenyia po sozdaniiu i obnovleniiu topohraficheskikh kart masshtabov 1:10,000, 1:25,000, 1:50,000, 1:100,000, 1:200,000, 1:500,000 i 1:1,000,000 (1984). Moskva: RIO VTS.

Sossa, R., \& Holubinka, Yu. (2017). Suchasni vyklyky do topoheodezychnoho ta kartohrafichnoho zabezpechennia sektoru bezpeky ta oborony derzhavy. Visnyk Kyivskoho natsionalnoho universytetu imeni Tarasa Shevchenka (Viiskovo-spetsialni nauky), 36 (1), 20-23.

Sossa, R. I. (2014). Topohrafichne kartohrafuvannia Ukrainy (1917-2012). Kyiv: Naukova dumka.

Zaiets, I. M., \& Kucher, O. V. (2006). Derzhavna heodezychna merezha. In Derzhavna kartohrafo-heodezychna sluzhba Ukrainy: 1991-2006 (pp. 55-56). Kyiv: NDIK. 